\title{
Edukasi Pemanfaatan Rempah Sebagai Minuman Untuk Pencegahan Covid-19 Di Kelurahan Debong Kulon
}

\author{
Trimar Handayani ${ }^{1}$, Dwi Uswatun Khasanah ${ }^{2}$ \\ ${ }^{1,2}$ Program Studi DIII Keperawatan Tegal \\ Politeknik Kesehatan Kementerian Kesehatan Semarang \\ Jl. Dewi Sartika No 1 Kota Tegal Telp (0283) 323524 \\ e-mail: ${ }^{13}$ marjamil@gmail.com, ${ }^{2}$ dwius.308@gmail.com
}

\begin{abstract}
Abstrak
Pandemi Covid-19 yang sedang melanda semua negara termasuk Indonesia membutuhkan penanganan yang cepat untuk memutus mata rantai penularannya. Cara pencegahan yang dapat digunakan antara lain dengan meningkatkan daya tahan tubuh atau imunitas individu. Peningkatan ini dapat dilakukan dengan berbagai cara, salah satunya dengan mengkonsumsi rutin minuman yang terbuat dari rempah-rempah yang banyak terdapat di Indonesia. Penggunaan dan pengelolaan rempah-rempah secara campuran/gabungan akan memberikan efek maksimal dalam membantu meningkatkan daya tahan tubuh. Kegiatan ini bertujuan untuk meningkatkan pengetahuan peserta tentang Covid-19 dan manfaat rempah serta menambah keterampilan peserta dalam pemanfaat rempah sebagai bahan minuman empon-empon. Metode yang digunakan meliputi edukasi dan praktek langsung pembuatan minuman secara daring dengan menggunakan media aplikasi Whatsapp dan Zoom. Evaluasi diukur dari peningkatan pengetahuan dan keterampilan sebelum dan sesudah pelaksanaan pengabdian masyarakat. Hasil yang dicapai setelah pelaksanaan kegiatan menunjukkan adanya peningkatan pengetahuan dan tingkat kepuasan yang baik dari para peserta. Setelah kegiatan berlangsung peserta mulai memanfaatkan dan dapat mengaplikasikan pembuatan minuman empon-empon dari rempah-rempah untuk diminum rutin selama masa pandemi.
\end{abstract}

Kata kunci: Covid-19, Imunitas, Rempah

\section{PENDAHULUAN}

Novel Coronavirus (SAR-CoV-2) atau yang saat ini lebih dikenal dengan penyakit Covid-19 telah menarik perhatian dunia selama beberapa bulan terakhir. Virus yang berasal dari Wuhan Cina ini memiliki patogenitas serta kemampuan menular yang kuat dan masih menyimpan banyak misteri yang belum terpecahkan. Saat ini pemerintah Indonesia sendiri berada dalam kondisi masih berjuang menghadapi virus yang sudah dinyatakan sebagai masalah dunia secara global dengan ditetapkannya penyakit ini menjadi pandemi Covid-19. Coronavirus merupakan virus RNA berukuran 120-160 nm. Pada manusia biasanya menyebabkan penyakit saluran pernafasan, mulai dari flu biasa hingga penyakit yang serius. Transmisi utama penyebaran virus ini dari manusia ke manusia sehingga penyebarannya menjadi lebih agresif. Transmisi terjadi melalui droplet yang keluar saat batuk atau bersin [1]. Ada banyak upaya yang sudah dilakukan untuk mengetahui lebih jauh bagaimana cara untuk terhindar dari penyebaran virus yang sangat cepat, salah satunya dengan meningkatkan imunitas tubuh agar tidak mudah terinfeksi dari virus tersebut. Cara preventif yang mulai banyak dikembangkan untuk mengetahui bahan yang dapat digunakan sebagai media untuk meningkatkan daya tahan tubuh yaitu, rempah-rempah yang juga merupakan tanaman herbal di Indonesia dan banyak tersedia di sekitar kita. Berdasarkan penelitian, rempah-rempah yang memiliki potensi untuk mencegah terkenanya virus Covid-19 saat ini dikenal dengan empon-empon, antara lain: kunyit, temulawak, jahe, sereh, dan kayu manis. Bahan rempah-rempah ini dapat bermanfaat sebagai antiviral, suplemen atau imunomodulator untuk 
menjaga daya tahan tubuh [2,3]. Melalui pengelolaan yang benar, senyawa-senyawa kimia dari rempah-rempah tersebut dapat dimanfaatkan secara maksimal, karena penggunaan secara tunggal maupun gabungan bisa membantu dalam meningkatkan daya tahan tubuh [4]. Oleh karena itu, pada kegiatan ini akan diberikan pengetahuan baik tentang penyakit Covid-19 maupun manfaat dari setiap rempah-rempah, serta mempraktekkan cara pembuatan minuman empon-empon yang dipercaya dapat membantu meningkatkan daya tahan tubuh selama masa pandemi.

\section{METODE}

Kegiatan pengabdian masyarakat ini diikuti oleh kader kesehatan yang ada di Kelurahan Debong Kulon Kota Tegal sebanyak 25 orang. Metode kegiatan dilakukan secara daring melalui beberapa tahapan yaitu: tahap edukasi tentang rempah-rempah dan penyakit Covid-19 melalui media Whatsapp (WA) group kader kesehatan, tahap praktek pembuatan minuman dengan menggunakan media Zoom yang melibatkan narasumber dari produsen minuman herbal, tahapan evaluasi dengan menggunakan media google form untuk pretest, post-test, dan survey kepuasan peserta. Media lain yang digunakan untuk mendukung kegiatan ini yaitu booklet yang berisikan materi dan cara pembuatan minuman rempah, bahan rempah-rempah, aplikasi Zoho untuk daftar hadir selama kegiatan. Rangkaian kegiatan pengabmas ini dilakukan secara daring dan membatasi pertemuan fisik karena masih dalam masa pandemi Covid-19.

\section{HASIL DAN PEMBAHASAN}

Hasil yang dicapai pada kegiatan pengabdian masyarakat yang telah dilaksanakan melalui beberapa tahap dari bulan Juni-Agustus 2020 ini sebagai berikut:

\subsection{Tahap edukasi pengetahuan tentang penyakit Covid-19 dan rempah-rempah}

Pada tanggal 26 Juni dan 28 Juni 2020 dilakukan edukasi secara bertahap melalui media WA group yang beranggotakan kader kesehatan. Edukasi yang diberikan meliputi pengertian, penyebab, cara penularan, pencegahan serta cara meningkatkan daya tahan tubuh supaya terhindar dari penyakit tersebut. Selain itu, edukasi tentang rempah-rempah yang sering dipakai sehari-hari pada saat memasak dan dapat dimanfaatkan dalam pembuatan minuman empon-empon yang berguna untuk meningkatkan daya tahan tubuh. Rempah untuk membuat empon-empon ini terdiri dari kunyit, temulawak, jahe, sereh dan kayu manis.

Kunyit atau lebih dikenal dengan curcumin merupakan tanaman obat yang berkhasiat sebagai antibakteri, antioksidan, antiinflamasi, anti kanker, penurunan gula darah dan juga imunomodulator. Pada pasien Covid-19 berdasarkan penelitian, infeksi virus SARS-CoV-2 memiliki kesamaan dengan SARS-CoV dan mengidentifikasi target potensial untuk intervensi antivirus. Curcumin memiliki efek menghambat proses pertumbuhan virus baik secara langsung dengan merusak fisik virus maupun melalui penekanan jalur pensinyalan seluler yang penting dalam proses replikasi virus. Penggunaan curcumin untuk tindakan preventif dalam mencegah Covid-19 sangat relevan berdasarkan penelitian pra klinik dan klinik yang terbukti memiliki efek imunomodulator yang dapat dikonsumsi sehari-hari agar menjaga kesehatan tubuh[3,5]. Temulawak bermanfaat dalam menetralkan racun, menghilangkan nyeri, antibakteri, mencegah perlemakan dalam sel hati, serta anti oksidan. Sereh memberikan khasiat sebagai penghambat pertumbuhan bakteri dan jamur karena mengandung minyak atsiri. Jahe memiliki sifat anti inflamasi sehingga dapat menghilangkan virus yang menyebabkan demam dan pilek serta memperbaiki pencernaan. Kayu manis merupakan anti oksidan yang berfungsi meningkatkan sistem kekebalan tubuh, selain itu juga memiliki sifat antivirus. Pemanfaatan tanaman rempah baik secara tunggal maupun gabungan dapat membantu dalam meningkatkan daya tahan tubuh sebagai imunomodulator $[4,6]$. 


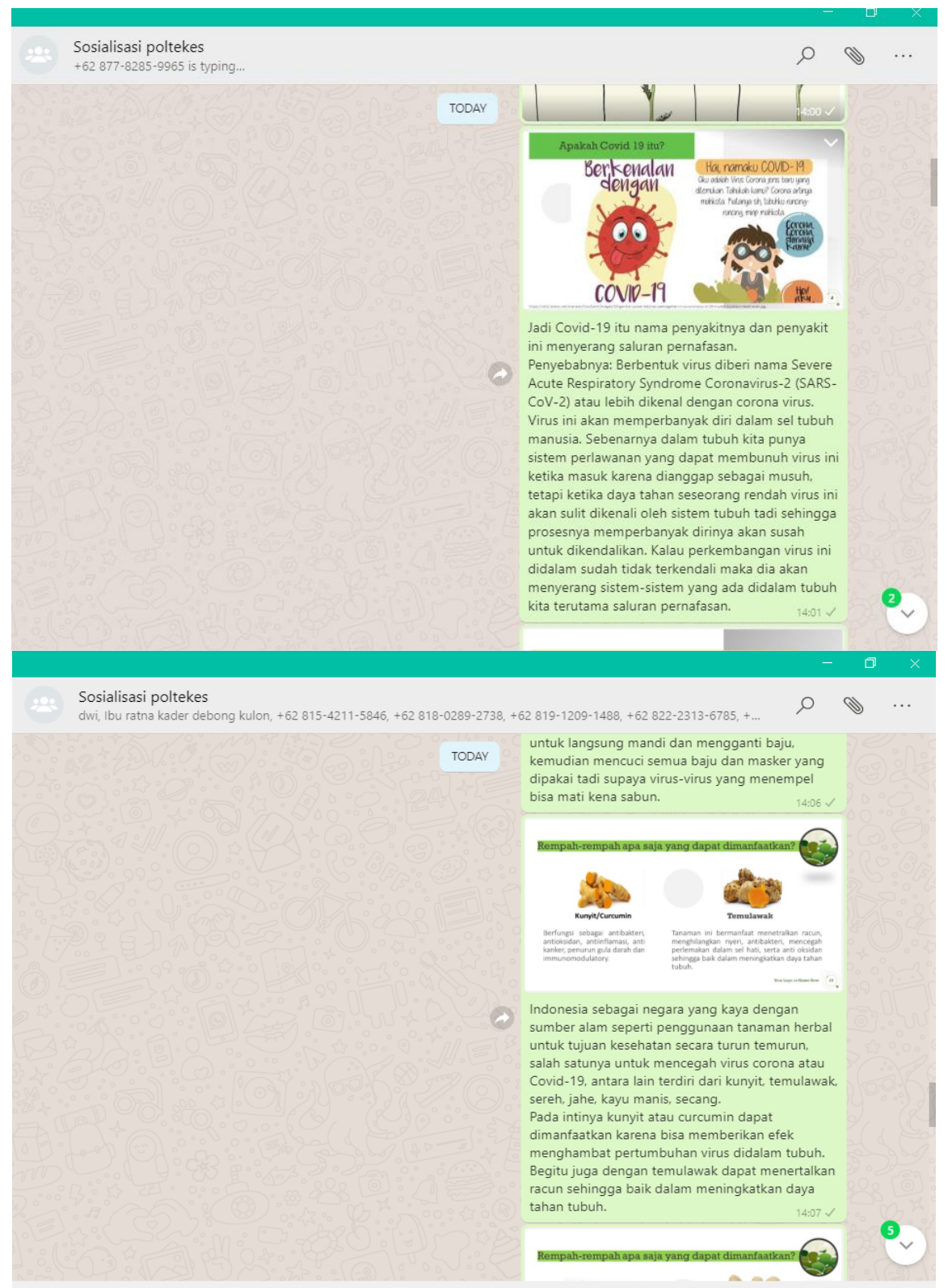

Gambar 1. Screenshot materi yang dibagikan pada pelaksanaan edukasi melalui group WA

Sebelum dan sesudah edukasi diberikan soal pretest dan post-test yang sama, sebanyak 10 pertanyaan melalui google form kepada para peserta. Hasil yang didapatkan dari nilai rerata jawaban yang benar pada saat post-test lebih tinggi yaitu 9,82 sedangkan hasil pada saat pretest hanya 7,64. Hal ini dapat disimpulkan bahwa telah terjadi peningkatan pengetahuan dari peserta setelah mengikuti kegiatan, sehingga edukasi yang diberikan dapat diterapkan dalam kehidupan sehari-hari. Notoadmodjo (2007) mengungkapkan bahwa pengetahuan merupakan hasil dari tahu, terjadi setelah penginderaan terhadap suatu objek tertentu. Sebagian pengetahuan manusia diperoleh melalui telinga dan mata. Peningkatan pengetahuan akan mempengaruhi perubahan prilaku peserta karena pengetahuan atau kognitif merupakan faktor dominan yang sangat penting untuk terbentuknya tindakan seseorang [7].

\subsection{Tahap praktek pembuatan minuman dari bahan rempah-rempah}

Dua hari sebelum praktek dimulai yaitu pada tanggal 01 Juli 2020, tim membagikan booklet dan bahan yang akan digunakan pada saat praktek kepada para peserta dengan tetap 
menerapkan protokol kesehatan dan tidak berkumpul. Kemudian kegiatan praktek dilakukan pada tanggal 02 Juli 2020 melalui media Zoom yang diikuti oleh semua peserta dan dipandu oleh narasumber. Semua peserta mengikuti kegiatan dari rumah masing-masing dan langsung mempraktekkan bersama-sama tahapan pembuatan minuman dengan menggunakan rempah serta dibantu juga dengan booklet yang sudah dibagikan. Setelah kegiatan selesai, kemudian dilakukan sesi tanya jawab antara peserta dan narasumber terkait cara pembuatan minuman rempah-rempah. Dari kegiatan ini peserta dapat mengetahui komposisi dan takaran yang pas dari masing-masing rempah-rempah yang dipakai untuk pembuatan minuman empon-empon sehingga dapat memberikan hasil yang maksimal. Peserta berpartisipasi aktif selama kegiatan berlangsung sehingga pelaksanaan dapat berjalan lancar. Selain itu keberhasilan suatu kegiatan pelatihan ditentukan oleh metode, sarana/fasilitas dan instruktur/narasumber [8].
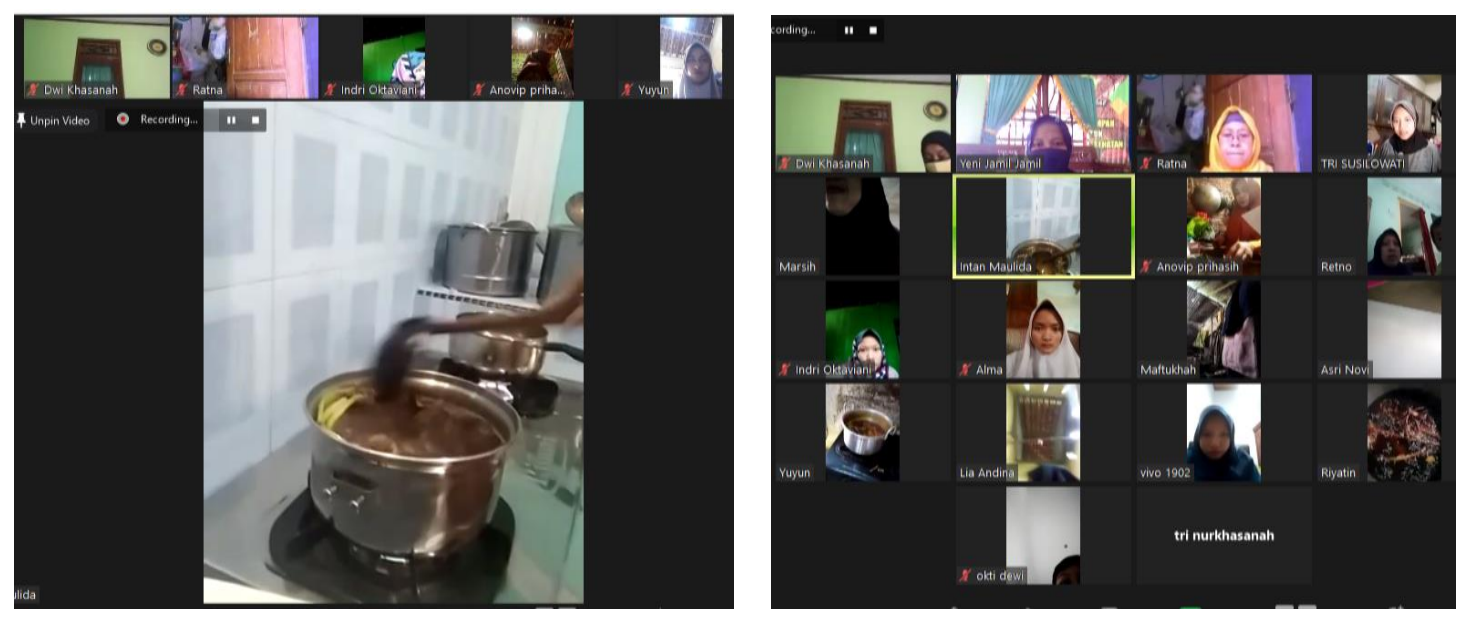

Gambar 2. Screenshot pelaksanaan praktek pembuatan minuman empon-empon dengan media Zoom

\subsection{Tahap Evaluasi}

Pada tahapan evaluasi, dilakukan monitoring melalui media WA terkait penerapan pembuatan minuman setelah kegiatan dilaksanakan. Monitoring ini dilakukan dengan mengirimkan gambar hasil pembuatan minuman secara mandiri di rumah. Peserta mengungkapkan bahwa pembuatan minuman ini sudah mereka laksanakan dirumah untuk dikonsumsi sehari-hari dan mereka mulai merasakan manfaatnya. Adanya peningkatan kemampuan peserta dalam pembuatan minuman ini merupakan salah satu tanda keberhasilan kegiatan [8].

Berdasarkan survey tingkat kepuasan selama pelaksanaan kegiatan didapatkan hasil bahwa $81 \%$ (21 peserta) merasa puas dengan pelaksanaan kegiatan karena memberikan manfaat yang sangat membantu meningkatkan pengetahuan dan kesehatan mereka terutama selama menghadapi masa pandemi. Menurut Kirkpatrik (2006) dalam Siregar (2017), ada empat tingkatan evaluasi model. Pada evaluasi level satu (reaction level), untuk mengukur kepuasan peserta pelatihan terhadap program pelatihan atau kegiatan yang diikuti oleh peserta. Kepuasan ini meliputi kepuasan kepada narasumber/instruktur, materi, penyampaian materi, fasilitas dan keseluruhan penyelenggaraan program. Asumsi yang mendasari reaction level ini adalah kepuasan yang menjadi motivasi belajar, ketika peserta menyukai atau puas dengan kegiatan yang diberikan maka peserta kemudian akan belajar sehingga pengetahuannya meningkat dan dapat mengaplikasikan materi tersebut pada kehidupan sehari-harinya[8]. 


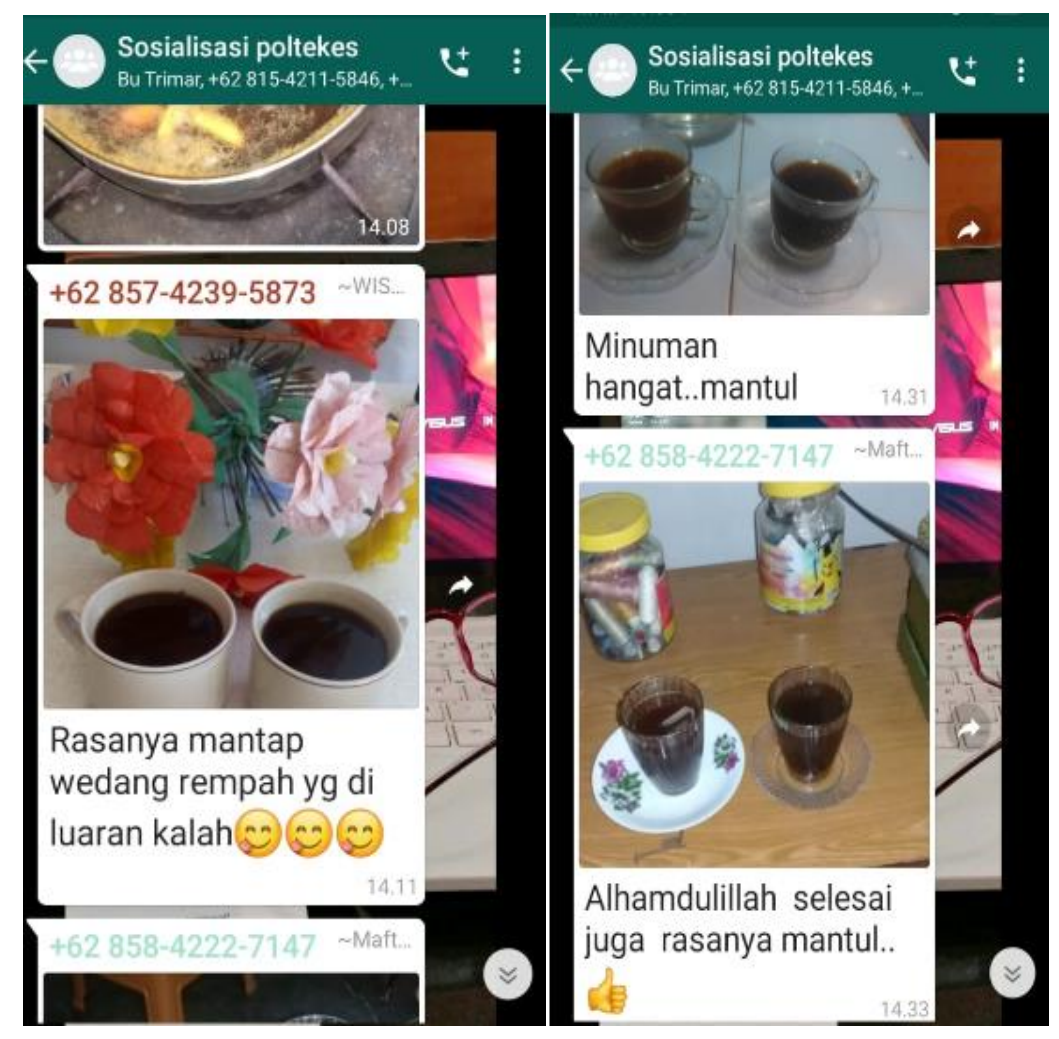

Gambar 3. Hasil pembuatan minuman pada saat dilakukan tahap evaluasi

\section{KESIMPULAN}

Secara keseluruhan pelaksanaan kegiatan pengabdian kepada masyarakat yang diadakan di Kelurahan Debong Kulon Kota Tegal berjalan lancar. Peserta telah memahami dan mengerti tentang penyakit Covid-19 serta proses pengolahan rempah-rempah yang menjadi bahan minuman untuk membantu meningkatkan daya tahan tubuh selama masa pandemi. Peserta juga telah berhasil mempraktekkan dan mengkonsumsi rutin minuman empon-empon dari hasil olahan rempah-rempah yang mereka buat secara mandiri di rumah.

\section{SARAN}

Saran yang disampaikan untuk masyarakat yaitu sebaiknya lebih sering memanfaatkan bahan rempah yang ada disekitar kita baik untuk bumbu masakan maupun untuk dibuat minuman yang dapat membantu meningkatkan daya tahan tubuh terutama di masa pandemi ini.

\section{UCAPAN TERIMA KASIH}

Penulis mengucapkan terima kasih kepada Poltekkes Kemenkes Semarang Prodi Keperawatan Tegal yang telah memberi dukungan finansial terhadap kegiatan Pengabdian Masyarakat ini. Serta kepada Lurah dan seluruh Kader Kesehatan Debong Kulon yang telah berperan serta aktif dan mendukung kegiatan ini.

\section{DAFTAR PUSTAKA}

[1] Susilo A, Rumende CM, Pitoyo CW, Santoso WD, Yulianti M, Sinto R, et al, 2020, Coronavirus Disease 2019: Tinjauan Literatur Terkini Coronavirus Disease 2019: Review of Current Literatures, Jurnal Penyakit Dalam Indonesia, vol 7(1), hal 45-67. 
[2] Nurul IS, Haryono G, 2018, Pengkajian beberapa tanaman empon - empon di Desa Balesari Kecamatan Windusari Kabupaten Magelang, Jurnal Ilmu Pertanian Tropika dan Subtropika, Vol 3(1), hal 13-6.

[3] Litbangkes Kemenkes RI, 2020, Curcumin, Aman Dikonsumsi Saat Pandemi Covid-19, http://www.b2p2toot.litbang.kemkes.go.id/index.php?page=postcont\&postid=189\&co

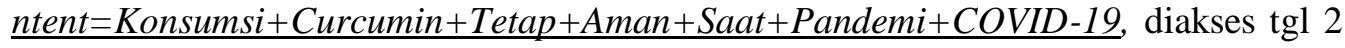
April 2020.

[4] Permana A, 2020, Manfaat Kunyit dan Temulawak Terhadap Penanganan Covid-19, https://www.itb.ac.id/news/read/57446/home/manfaat-kunyit-dan-temulawak-terhadap -penanganan-covid-1, diakses tgl 2 April 2020

[5] Hoffmann M, Hannah K-W, Simon S, 2020, SARS-CoV-2 Cell Entry Depends on ACE2 and TMPRSS2 and Is Blocked by a Clinically Proven Protease Inhibitor. Cell,Elsevier, 181, hal 271-80.

[6] Kementerian Kesehatan RI, 2011, 100 Top Tanaman Obat Indonesia, Cetakan 1. Kementerian Kesehatan RI-Balai Besar Litbang Tanaman Obat dan Obat Tradisional, hal 1-214, http://online.anyflip.com/wmni/yron/mobile/index.html\#p=3, diakses tanggal 30 maret 2020.

[7] Notoadmodjo S, 2007, Kesehatan Masyarakat Ilmu dan Seni, Jakarta: PT Rineka Cipta.

[8] Siregar, VO, 2017, Hubungan Kepuasan Peserta Pelatihan Dengan Tingkat Pembelajaran Peserta Pelatihan Pencegahan Dan Pengendalian Infeksi. Jurnal Administrasi Kesehatan Indonesia, vol 5, hal 62-71. 